\title{
A NEW GENUS AND SPECIES OF CHAPERIIDAE (BRYOZOA: CHEILOSTOMATA) FROM THE EARLY MIOCENE OF PATAGONIA (ARGENTINA)
}

\author{
JUAN LÓPEZ-GAPPA ${ }^{1,3}$, AND LEANDRO M. PÉREZ2,3
}

\begin{abstract}
1Museo Argentino de Ciencias Naturales. Av. Ángel Gallardo 470, 1405 Ciudad Autónoma de Buenos Aires, Argentina. Igappa@macn.gov.ar 2División Paleozoología Invertebrados, Museo de Ciencias Naturales, Paseo del Bosque s/n, 1900 La Plata, Argentina. pilosaperez@gmail.com ${ }^{3}$ Consejo Nacional de Investigaciones Cientificas y Técnicas (CONICET), Argentina.
\end{abstract}

\begin{abstract}
The family Chaperiidae reaches its highest biodiversity in the southern hemisphere. The main morphological feature characterizing the family is a pair of calcareous laminar structures associated with the insertion of the operculum occlusor muscles. The aim of this study is to describe Aluis spinettai gen. et sp. nov., from material collected in the Monte León, the Chenque and the Puesto del Museo formations (early Miocene, Patagonia, Argentina). A. spinettai has erect bilaminar colonies, crenulated sutures between zooids, an extensive cryptocyst and spherical ovicells; gymnocyst, oral spines and avicularia are absent. The new species exhibits a remarkable morphological convergence with a species of Aspidostoma from the early Miocene (Chenque Formation) of Patagonia. In some areas of the colony, the cryptocysts were pierced by circular drill holes made by an unknown predator. The stratigraphic distribution of $A$. spinettai ranges from $\sim 19$ to 17 Ma (Burdigalian). Its presence suggests a correlation between the upper levels of the Monte León Formation and the lower levels of the Chenque Formation. The paleogeographic distribution of this new species spans at least $500 \mathrm{~km}$ along the southern Atlantic coast of South America. The living representatives of the Chaperiidae in the Southwest Atlantic do not seem related with A. spinettai.
\end{abstract}

Key words. Cheilostome bryozoan. Predatory drill holes. Monte León Formation. Chenque Formation. Puesto del Museo Formation.

Resumen. UN NUEVO GÉNERO Y ESPECIE DE CHAPERIIDAE (BRYOZOA: CHEILOSTOMATA) DEL MIOCENO TEMPRANO DE PATAGONIA (ARGENTINA). La familia Chaperiidae alcanza su máxima biodiversidad en el hemisferio sur. El principal rasgo morfológico que caracteriza a la familia es un par de láminas calcáreas asociadas con la inserción de los músculos oclusores del opérculo. El propósito de este trabajo es describir a Aluis spinettaigen. et sp. nov., a partir de material obtenido en las Formaciones Monte León, Chenque y Puesto del Museo (Mioceno temprano, Patagonia, Argentina). A. spinettai posee colonias erectas bilaminares, suturas crenuladas entre los zooides, un extenso criptocisto y ovicelas esféricas, y carece de gimnocisto, espinas orales y avicularias. La nueva especie exhibe una notable convergencia morfológica con una especie del género Aspidostoma del Mioceno temprano (Fm. Chenque) en Patagonia. En algunas zonas de la colonia los zooides presentaban perforaciones circulares en el criptocisto realizadas por un depredador desconocido. A. spinettai presenta una distribución estratigráfica que va desde 19 a $17 \mathrm{Ma}$ (Burdigaliano). Su presencia sugiere una correlación entre los niveles superiores de la Formación Monte León y los inferiores de la Formación Chenque. La distribución paleogeográfica de esta nueva especie abarca al menos 500 km a lo largo de la costa atlántica austral de Sudamérica. Los representantes actuales de la familia Chaperiidae en el Atlántico Sudoccidental no parecen relacionados con A. spinettai.

Palabras clave. Briozoo queilostomado. Orificios perforados por depredadores. Formación Monte León. Formación Chenque. Formación Puesto del Museo.

THE FAMILY Chaperiidae, established by Jullien (1888), has an almost worldwide distribution but reaches its highest biodiversity in the southern hemisphere. It nowadays consists of 13 genera whose stratigraphic range extends from the Cretaceous to Recent. While Amphiblestrella Prud'homme, 1961, Bryochaperia Zágorsek, 2001 and Catenariopsis Maplestone, 1899 are entirely fossil, the remaining genera are either exclusively Recent or have both fossil and Recent representatives.

The main morphological feature characterizing the family is a pair of calcareous laminar structures associated with the insertion of the operculum occlusor muscles that were called "occlusor laminae" by Harmer (1926). Gordon (1982) published a valuable review of the family, providing a sound taxonomic framework and a key to the genera mainly based on the presence/absence and the characteristics of the oral spines, avicularia and ovicells.

In the Recent marine fauna of the southern Southwest Atlantic, the family is represented by species of Chaperia Jullien, 1888 and Chaperiopsis Uttley, 1949. These are Chaperia 
acanthina (Lamouroux, 1825), Chaperia taylori Ramalho and Calliari, 2015, Chaperiopsis auriculata Hayward and Winston, 2011, Chaperiopsis cervicornis (Busk, 1854), Chaperiopsis erecta (Busk, 1884), Chaperiopsis galeata (Busk, 1854), Chaperiopsis indefensa Hayward and Thorpe, 1988, Chaperiopsis orbiculata Hayward and Thorpe, 1988, Chaperiopsis patulosa (Waters, 1904) and Chaperiopsis propinqua Hayward and Thorpe, 1988 (see López Gappa, 2000). The fossil record of the Chaperiidae in southern South America is scarce. Only Chaperia acanthina, C. galeata, and C. laticella Canu, 1908 are known from Miocene localities in the Province of Chubut, Argentine Patagonia (Canu, 1908).

The aim of this study is to describe a new genus and species of Chaperiidae found in early Miocene formations of the provinces of Santa Cruz and Chubut, Argentina.

\section{GEOLOGICAL SETTING}

The marine Neogenic sedimentary units of Argentina extend along the Atlantic coast of Patagonia, between the provinces of Río Negro and Tierra del Fuego. Among the various outcrops on the coast representing this segment of geological time, the Miocene units are particularly interesting due to their high diversity of macroinvertebrates. The Chenque and Monte León Formations, separated by 500 km, outcrop in the provinces of Chubut and Santa Cruz, respectively (Fig. 1). The former is exposed in Punta del Marqués, near the city of Comodoro Rivadavia (Cuitiño et al., 2015) while, the latter, is mainly located at the Parque Nacional Monte León (Parras and Griffin, 2009; Parras et al., 2012).

The Chenque and Monte León formations are partially contemporary units originated in a relatively low-energy, shallow marine environment (Cuitiño et al., 2015; del Río et al., 2018). Among the macroinvertebrate fauna represented in these units, the Bryozoa is one of the most abundant and best-preserved phyla. Cenozoic bryozoans in the Patagonian region were initially studied by Ortmann (1900, 1902) and Canu (1904, 1908, 1911), and, more recently, by Pérez et al. (2015a,b; 2018) and López-Gappa et al. (2017, 2018).

Based on the isotopic analysis of $\mathrm{Sr}^{87} / \mathrm{Sr}^{86}$, ages of 19.6 to $17 \mathrm{Ma}$ and 17.9 Ma (Burdigalian) were obtained for the base of the Chenque Formation (Cuitiño et al., 2015) and the top of the Monte León Formation (Parras et al., 2012), re- spectively. Further information on the fossil associations and the geological setting of these stratigraphic units can be found in Bellosi (1990), Paredes and Colombo (2001), Cuitiño et al. (2015) and Carmona et al. (2008).

Another sedimentary unit between Punta del Marqués and Monte León is the Puesto del Museo Formation (Panza, 1998). Although it contains fossil macroinvertebrates, it is mainly known as 'Piedra Museo', an archaeological site that confirms early human activity in the Patagonian region (Miotti, 1992). This formation, currently under study (Gómez-Peral et al., in prep.), is characterized by a $\sim 20$ mthick homogeneous succession of friable, cross-bedding grainstones.

\section{METHODS}

Measurements were taken with a micrometer eyepiece under a Zeiss stereomicroscope. Colonies were coated with gold/palladium and images were obtained using a SEM

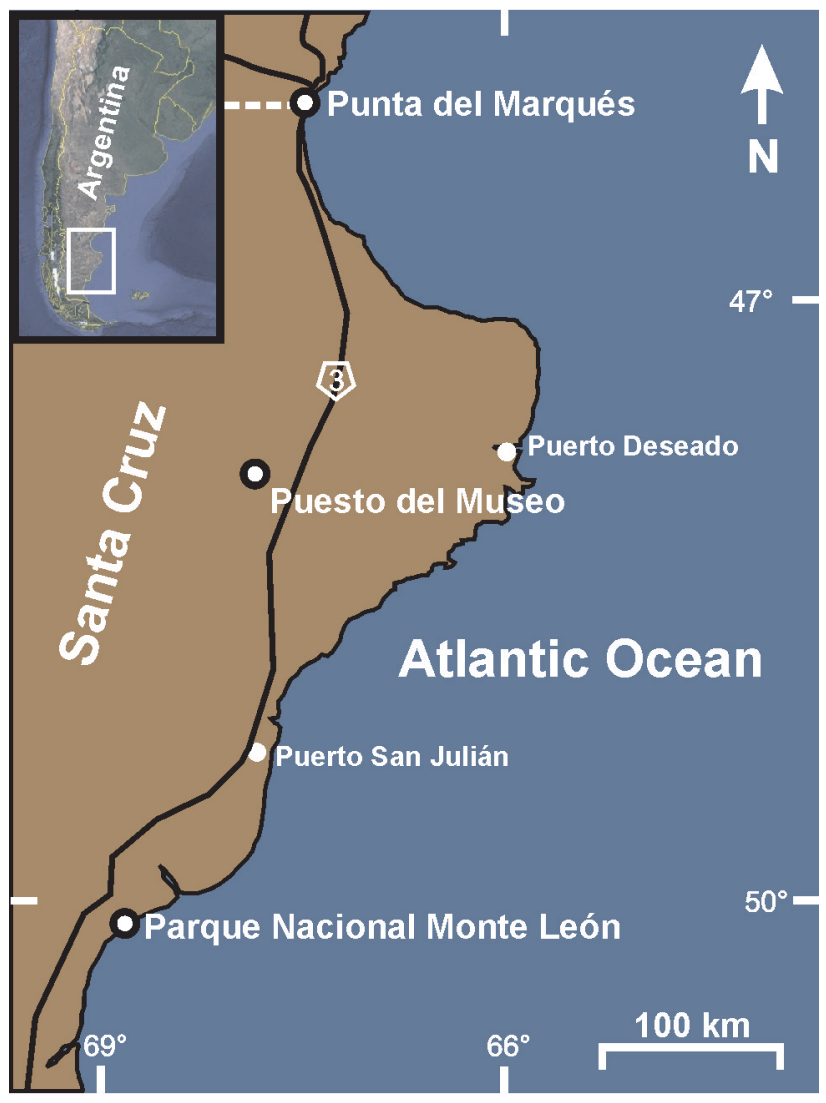

Figure 1. Map of study area and localities mentioned in the text: Punta del Marqués, Puesto del Museo and Parque Nacional Monte León. 
(Phillips XL-30) at Museo Argentino de Ciencias Naturales.

Institutional abbreviations. Museo de La Plata "Francisco P. Moreno", La Plata, Province of Buenos Aires (MLP). Museo Egidio Feruglio, Trelew, Province of Chubut (MEF). Museo Argentino de Ciencias Naturales "Bernardino Rivadavia", Ciudad Autónoma de Buenos Aires (MACN).

\section{SYSTEMATIC PALEONTOLOGY}

Phylum BryozoA Ehrenberg, 1831

Class Gymnolaemata Allman, 1856

Order Cheilostomata Busk, 1852

Family CHAPERIIDAE Jullien, 1888

Genus Aluis gen. nov.
Type species. Aluis spinettaisp. nov., by monotypy.

Derivation of name. The name chosen for the new genus and species honours the memory of the Argentine musician and composer Luis Alberto Spinetta (1950-2012).

Diagnosis. Colony bilaminar. Zooids separated by crenulated margins. Occlusor laminae well developed. Cryptocyst extensive, coarsely granular, with one pair of processes distolaterally to the opesia. Gymnocyst, oral spines and avicularia absent. Ovicell globular, recumbent on the cryptocyst of the following zooid. Communication between zooids by pore plates.

Remarks. In addition to Aluis gen. nov., the only other genus of Chaperiidae without avicularia and oral spines is Exallozoon Gordon, 1982 (Tab. 1). The latter, however, is characterized by the negligible development of the cryptocyst, which is extensive in the new genus.

TABLE 1 - The genera of the Chaperiidae: morphological features, mainly based on their type species

\begin{tabular}{|c|c|c|c|c|c|c|c|}
\hline Genus & $\begin{array}{l}\text { Colony growth } \\
\text { form }\end{array}$ & Cryptocyst & Gymnocyst & $\begin{array}{c}\text { Occlusor } \\
\text { laminae/arch }\end{array}$ & Oral spines & Avicularia & Ovicell \\
\hline Aluis gen. nov. & Erect, bilaminar & Extensive & Absent & Well developed & Absent & Absent & Globular \\
\hline $\begin{array}{l}\text { Amphiblestrella } \\
\text { Prud'homme, } 1961\end{array}$ & $\begin{array}{l}\text { Encrusting or } \\
\text { erect cylindrical }\end{array}$ & Well developed & Absent & Fused in an arch & Absent & Interzooidal & Immersed \\
\hline $\begin{array}{l}\text { Bryochaperia } \\
\text { Zágorsek, } 2001\end{array}$ & $\begin{array}{l}\text { Erect, } \\
\text { columnar }\end{array}$ & Well developed & Not developed & $\begin{array}{l}\text { Occlusor muscle } \\
\text { scars }\end{array}$ & Absent & Adventitious & Endozoecial \\
\hline $\begin{array}{l}\text { Catenariopsis } \\
\text { Maplestone, } 1899\end{array}$ & Uniserial & Well developed & Extensive & Fused centrally & Present & Absent & Present \\
\hline Chaperia Jullien, 1888 & $\begin{array}{l}\text { Encrusting, } \\
\text { unilaminar }\end{array}$ & Extensive & Absent & Well developed & Present & Absent & Absent \\
\hline Chaperiopsis Uttley, 1949 & $\begin{array}{l}\text { Encrusting, } \\
\text { unilaminar }\end{array}$ & Narrow & $\begin{array}{l}\text { Present } \\
\text { proximally }\end{array}$ & $\begin{array}{c}\text { Poorly } \\
\text { developed }\end{array}$ & Present & Adventitious & Hood-like \\
\hline $\begin{array}{l}\text { Clipeochaperia } \\
\text { Uttley and Bullivant, } 1972\end{array}$ & Encrusting & Narrow & Reduced & $\begin{array}{c}\text { Weakly } \\
\text { developed }\end{array}$ & Present & $\begin{array}{l}\text { Adventitious, } \\
\text { vicarious }\end{array}$ & Subimmersed \\
\hline Exallozoon Gordon, 1982 & $\begin{array}{l}\text { Encrusting, } \\
\text { unilaminar }\end{array}$ & Negligible & Reduced & $\begin{array}{l}\text { Moderately } \\
\text { developed }\end{array}$ & Absent & Absent & Prominent \\
\hline Exostesia Brown, 1948 & $\begin{array}{c}\text { Erect, } \\
\text { cellariiform }\end{array}$ & Present & $\begin{array}{l}\text { Obscured by } \\
\text { avicularia }\end{array}$ & Arch complete & Present & Adventitious & Small, cap-like \\
\hline Icelozoon Gordon, 1982 & Uniserial & Well developed & Broad, smooth & Well developed & Present & Absent & Hood-like \\
\hline Larnacicus Norman, 1903 & $\begin{array}{l}\text { Encrusting, } \\
\text { unilaminar }\end{array}$ & Extensive & Negligible & Well developed & Present & Interzooidal & Prominent \\
\hline $\begin{array}{l}\text { Notocoryne } \\
\text { Hayward and Cook, } 1979\end{array}$ & $\begin{array}{c}\text { Erect, } \\
\text { claviform }\end{array}$ & Broad & $\begin{array}{l}\text { Reduced, } \\
\text { indistinct }\end{array}$ & Stout distal arch & Present & Adventitious & Spherical \\
\hline Patsyella Brown, 1948 & $\begin{array}{l}\text { Encrusting, } \\
\text { unilaminar }\end{array}$ & Extensive & Not apparent & $\begin{array}{l}\text { Vertical ridges } \\
\text { on distal wall }\end{array}$ & Absent & Interzooidal & Immersed \\
\hline $\begin{array}{l}\text { Pyrichaperia } \\
\text { Gordon, } 1982\end{array}$ & $\begin{array}{l}\text { Encrusting, } \\
\text { multilaminar }\end{array}$ & Well-developed & Reduced & $\begin{array}{c}\text { Weakly } \\
\text { developed }\end{array}$ & Present & Absent & Prominent \\
\hline
\end{tabular}




\section{Aluis spinettai sp. nov.}

Figures 2-3, Table 2

Type material. Holotype MLP 36145. Paratypes, 4 fragments, MLP 36146-9. Monte León Formation.

Other material. MPEF-PI 6513, two fragments, Chenque Formation.

Geographic and stratigraphic occurrence. 'Cabeza de León' $\left(50^{\circ} 21^{\prime} 25.38^{\prime \prime} \mathrm{S} ; 68^{\circ} 53^{\prime} 5.88^{\prime \prime} \mathrm{W}\right)$, a locality within Parque Nacional Monte León, Province of Santa Cruz, in the Punta Entrada Member of the Monte León Formation (early

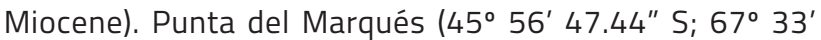
$13.75^{\prime \prime}$ W), Province of Chubut. Chenque Formation. Poorly preserved fragments of this species were also observed among the bioclasts composing the rock in the basal levels of the Puesto del Museo Formation (470 53' 48.45" S; 67051' 49.56" W; Panza, 1998; Gómez-Peral et al., in prep.). Diagnosis. Colony erect, bilaminar, anastomosing. Occlusor laminae well-developed, subparallel. Opesia wider than long. Cryptocyt extensive. Gymnocyst absent. Ovicell globular, recumbent on the cryptocyst of the following zooid. Oral spines and avicularia absent.

Description. Colony erect, bilaminar, anastomosing. In some instances, supplementary layers grow upon the older ones. Autozooids robust, hexagonal, ordered in quincunx (Fig. 2.1), well delimited by crenulated sutures (Fig. 2.2 inset) extending almost to the base of the zooid, longer than wide (length-to-width ratio: $\sim 1.2$ ). Opesia sunken in the middle
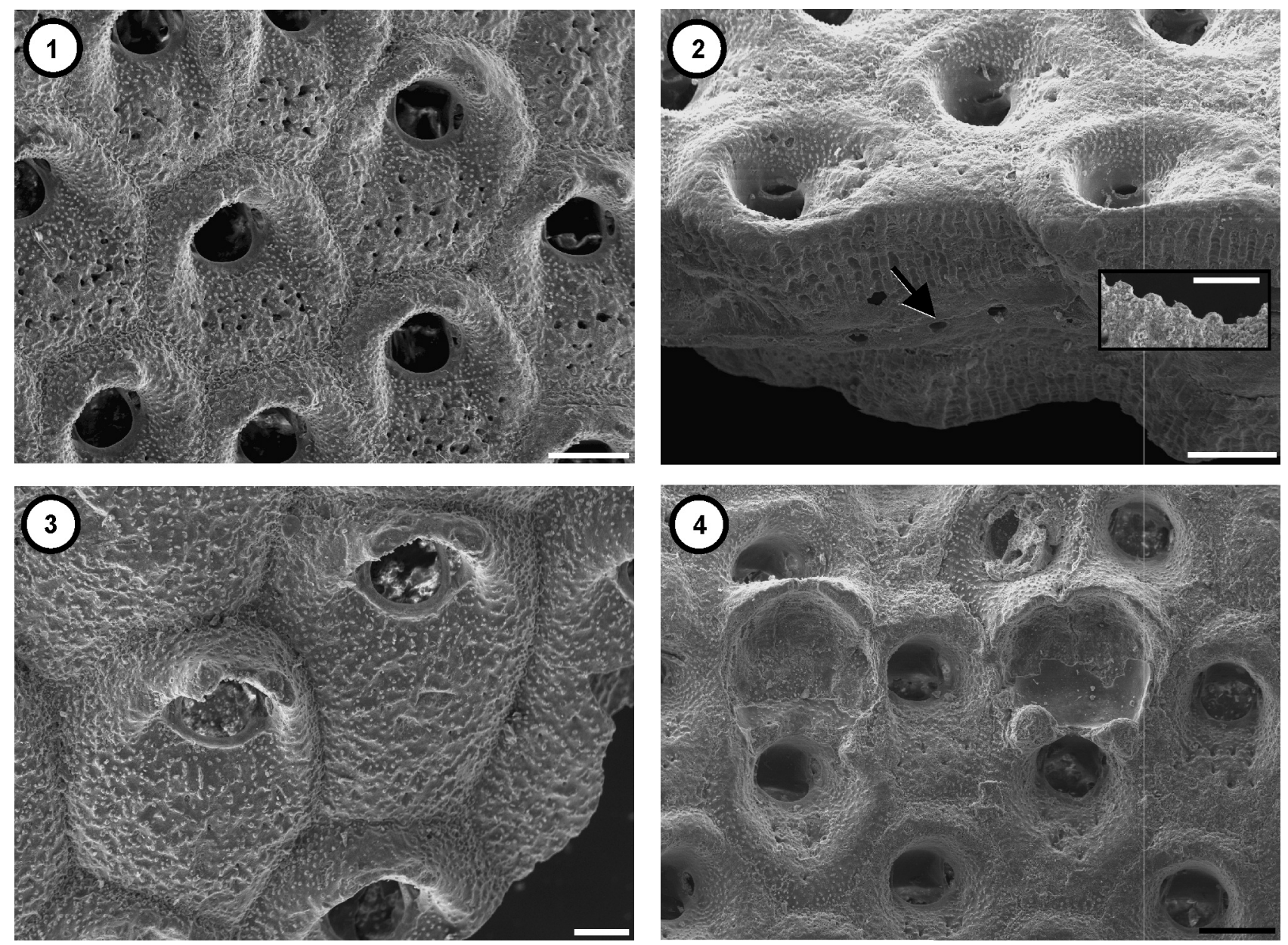

Figure 2. 1-4, Aluis spinettai gen. et sp. nov.; 1, Holotype, general aspect (MLP 36145); 2, Paratype (MLP 36148), lateral view of a bilaminar fragment. The crenulated margin extends almost towards the base of the zooid. The arrow shows one pore plate. Inset: Paratype (MLP 36148), detail of the crenulated margin; 3, Paratype (MLP 36146), zooids from a supplementary layer showing conspicuous disto-lateral processes. Note the coarsely granular cryptocyst; 4, Paratype (MLP 36147), two incomplete ovicells and fertile zooids with well-developed disto-lateral processes. Note the incised ovicell before a zooidal row bifurcation. Scale bars $=200 \mu \mathrm{m}(1,2,4)$, and $100 \mu \mathrm{m}(3$, inset). 


\begin{tabular}{lllll}
\hline \hline \multicolumn{4}{l}{$\begin{array}{l}\text { TABLE 2 } \\
\text { from Monte León Formation }\end{array}$} \\
\hline $\begin{array}{l}\text { Zooid } \\
\text { length }\end{array}$ & $\begin{array}{l}\text { Zooid } \\
\text { width }\end{array}$ & $\begin{array}{c}\text { Opesia } \\
\text { length }\end{array}$ & $\begin{array}{c}\text { Opesia } \\
\text { width }\end{array}$ \\
\hline Mean & 0.65 & 0.57 & 0.16 & 0.24 \\
\hline Minimum & 0.57 & 0.52 & 0.14 & 0.22 \\
Maximum & 0.73 & 0.61 & 0.18 & 0.26 \\
\hline Standard Deviation & 0.05 & 0.03 & 0.01 & 0.01 \\
\hline \hline
\end{tabular}

of the zooid, wider than long, its length representing about $24 \%$ the length of the zooid. Occlusor laminae well developed, subparallel, slightly converging towards the distal margin of the opesia. Cryptocyst extensive, coarsely granular, depressed towards the opesia, pierced by minute, rounded or irregular pores scattered throughout the frontal surface, except around the opesia, with one pair of disto-lateral processes located distally to the opesia. The granules of the cryptocyst tend to be arranged in vertical series around the opesia (Fig. 2.2). Zooids from the supplementary layers growing upon the bilaminar colony have well-developed distal processes (Fig. 2.3). Gymnocyst absent. Communication between zooids by pore plates in the base of the lateral walls (Fig. 2.2). Oral spines and avicularia absent. Ovicell globular, recumbent on the cryptocyst and almost reaching the proximal margin of the opesia of the following zooid (Fig. 2.4). The maternal zooid usually shows welldeveloped disto-lateral processes. The base of the ovicell appears incised when preceding a bifurcation of zooidal rows (Fig. 2.4). The ovicelled zooids do not display sexual dimorphism, i.e. the size and proportions of the opesia are similar to those of the remaining zooids. Zooids with the opesia occluded by calcification are occasionally seen (Fig. 3.1); their frontal surfaces are pierced by scattered pores. Ancestrula and early astogeny not seen.

Remarks. In some areas of the colony, we observed drill holes piercing the frontal surface (Fig. 3.2-3) made by an unknown but presumably small predator. The circular holes drilled in the cryptocyst are similar to those described by Wilson and Taylor (2006) in Recent colonies of Microporella hyadesi (Jullien, 1888), from the Southwest Atlantic and in North American Devonian hederellids. In the present case, however, they were not patched by the regeneration of new skeleton, as in M. hyadesi. There are 1-4 per zooid (Fig. 3.23), and their diameter is fairly constant (around 40-60 $\mu \mathrm{m}$ ) and with straight margins. They occur in different positions, mainly laterally and proximally to the opesia, but not along the distal zooidal margin.

As all the ovicells of $A$. spinettai were broken or incomplete, we ignore further details about their frontal surface. They are recumbent on the frontal surface of the next zooid and seem to be hyperstomial.

Most species of Chaperiidae have encrusting colonies. Bilaminar, anastomosing colonies are not common, but some cases are known in southern species of Chaperiopsis, such as C. bilaminata (Waters, 1898) from South Africa, C. columella (Brown, 1952) from the New Zealand Oligocene, $C$. multifida (Busk, 1884) from South Africa and the Kermadec Ridge (see Gordon, 1984), C. paulensis (Kluge, 1914) from Saint Paul Island, and C. splendida Gordon, 1986 from New Zealand. According to Brown (1952), colonies of Patsyella dentata (Waters, 1887) may be encrusting, unilamellar or bilamellar.

The zooids of $A$. spinettai gen. et sp. nov. from Punta del Marqués (Chenque Formation) (Fig. 3.4) were identical, although slightly larger, to those of the Monte León Formation (length: 0.65-0.81 mm, SD: 0.04, width: 0.54-0.63 mm, SD: 0.03).

The type material of Chaperia laticella Canu, 1908 consists of two colonies encrusting a brachiopod shell (MACNPi No. 1917). Canu's species differs from Aluis spinettai gen. et sp. nov. in being encrusting and lacking crenulated sutures and distal protuberances. The occlusor laminae are oblique and fused together towards the distal margin of the opesia. The spaces for the passage of the occlusor muscles are narrower than in $A$. spinettai. The opesia is somewhat pyriform and relatively large, its length representing about $48 \%$ of the length of a zooid. The shape of the zooids is variable and usually wider than long (length-to-width ratio: $\sim 0.8$ ).

Canu (1908) found two other species of Chaperiidae in the Miocene material from Patagonia. The specimen identified by Canu (1908) as Chaperia acanthina (MACN-Pi No. 1916) is an encrusting colony on the same shell as C. laticella. Its state of preservation is poor, preventing its identification at the specific level. Canu's (1908) material recorded as Chaperia galeata (MACN-Pi No. 1915) is a well-preserved 

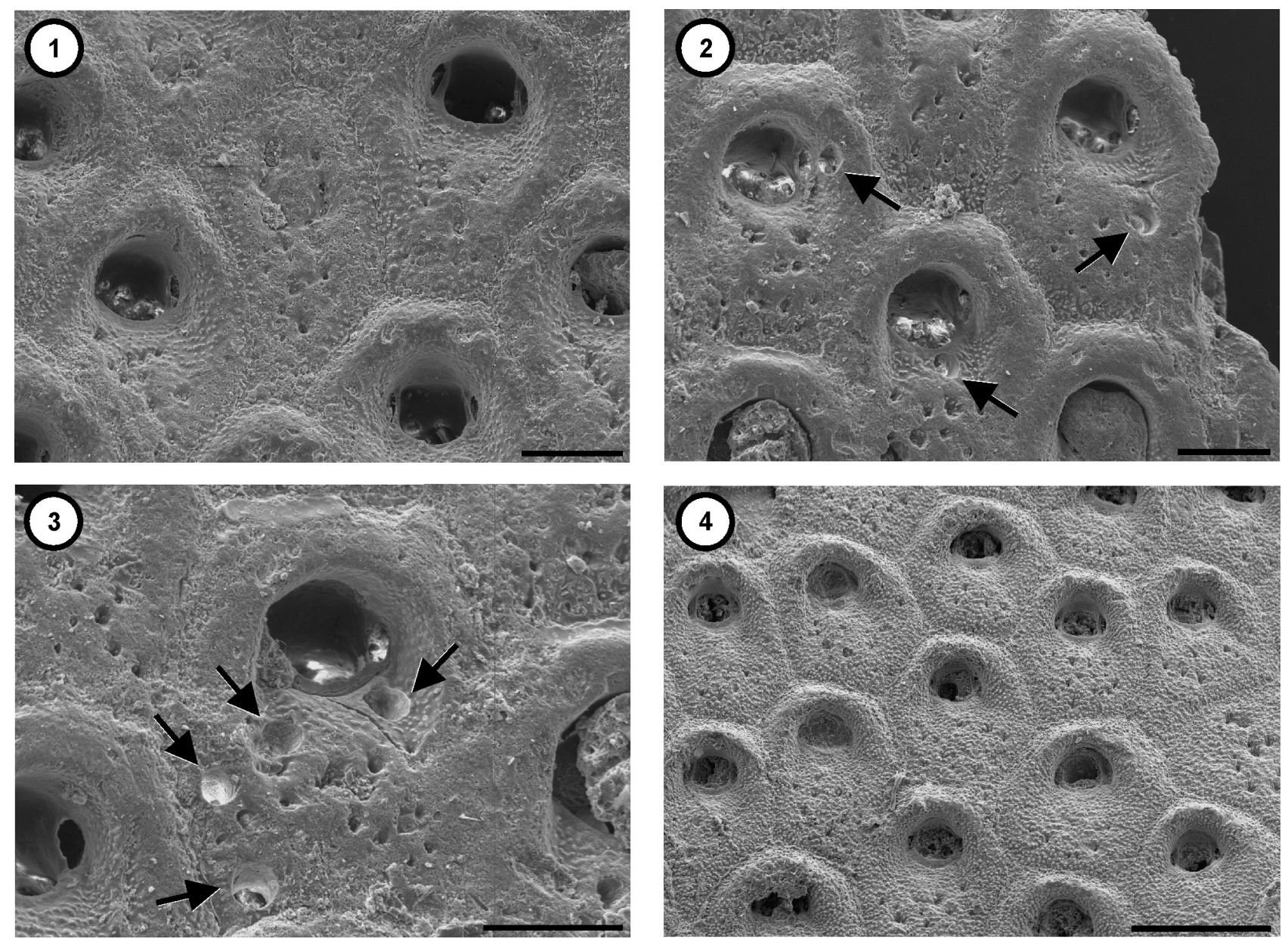

Figure 3. 1-4, Aluis spinettai gen. et sp. nov.; 1, Paratype (MLP 36147), zooid occluded by calcification; 2, Paratype (MLP 36149), three zooids with one drill hole each (shown by arrows); 3, Paratype (MLP 36149), detail of one zooid with four drill holes (pointed by arrows); 4, General aspect of a specimen from Chenque Formation (MPEF-PI 6513). Scale bars= $200 \mu \mathrm{m}(1-3)$ and $500 \mu \mathrm{m}$ (4).

colony of a species of Chaperiopsis encrusting an oyster. Its zooids have one pair of adventitious avicularia proximal to the opesia. The ovicell is hood-like, with a narrow transverse fenestra and an associated avicularium distal to it. The occlusor laminae are small and scarcely visible in frontal view. The cryptocyst is narrow. Spine bases are preserved in the zooid disto-lateral corners.

\section{DISCUSSION}

The paleogeographic distribution of Aluis spinettai gen. et sp. nov. spans more than $500 \mathrm{~km}$ along the southern Atlantic coast of South America. Together with Melychocella biperforata Pérez et al., 2018, M. flammula (Canu, 1908) and Aspidostoma incrustans Canu, 1908 (see Pérez et al., 2018), this new chaperiid suggests a biostratigraphic correlation between the upper levels of the Monte León Formation and the lower levels of the Chenque Formation during the early Miocene. Aluis spinettai gen. et sp. nov. has a stratigraphic distribution ranging from at least 19 to $17 \mathrm{Ma}$ (Burdigalian, early Miocene; Parras et al., 2012; Cuitiño et al., 2015).

Hayward and Thorpe (1988) described 16 species of Chaperiopsis based on extensive collections gathered during British surveys to Antarctica, the Scotia Arc and the Patagonian Shelf. All of them are encrusting and spinose while most have sessile or pedunculate avicularia. On the other hand, the living species of Chaperiidae inhabiting warmtemperate waters off the Brazilian coast belong to Chaperia [Chaperia acanthina (see Marcus, 1955), C. brasiliensis Vieira et al., 2010, and C. taylori Ramalho and Calliari, 2015]. The material recorded as Chaperia acanthina var. polygonia Kluge, 
1914 by López Gappa and Lichtschein (1988) for the continental shelf off the Province of Buenos Aires (Argentina) may prove to be conspecific with $C$. taylori.

Aluis spinettaigen. et sp. nov. shows an interesting morphological convergence with some South American Miocene species of Aspidostoma and, particularly, with Aspidostoma tehuelche Pérez et al., 2018, a species hitherto only found in the Chenque Formation. Both species have erect, bilaminar colonies, crenulated zooidal margins, a pair of protruding processes distal to the opesia, a depressed central area in the middle of the frontal surface, a coarsely granular cryptocyst pierced by scattered pores, and the occasional presence of zooids occluded by frontal calcification. However, $A$. spinettaigen. et sp. nov. differs from A. tehuelche in the presence of occlusor laminae and in the absence of a quadrangular process in the proximal margin of the opesia.

Aluis gen. nov. is the fourth exclusively fossil genus of the Chaperiidae. The living representatives of the family in the southwest Atlantic do not seem to be related to $A$. spinettaigen. et sp. nov.

\section{ACKNOWLEDGEMENTS}

We are grateful to G. Pastorino (MACN, Buenos Aires, Argentina) and M. Griffin (MLP, La Plata, Argentina) for collecting the material from Monte León. E. Di Martino, L. Ramalho, and A. Otero made useful comments on an earlier version of the manuscript. M. Longobucco allowed us to access Canu's material, stored in the MACN-Pi collection. F. Tricárico operated the Scanning Electron Microscope at MACN. The financial support provided by CONICET (PIP 2013-2015 No. 00247 to JLG and PIP 2015-2017 No. 1122015-0100523 CO to LMP) is acknowledged. And thanks Luis Alberto, for all the beauty you gave us.

\section{REFERENCES}

Allman, G.J. 1856. A Monograph of the Freshwater Polyzoa, including all the known 484 species, both British and Foreign. The Ray Society, London, $119 \mathrm{p}$.

Bellosi, E.S. 1990. Formación Chenque: Registro de la transgresión patagoniana (Terciario medio) de la cuenca de San Jorge, Argentina. Actas XI Congreso Geológico Argentino (San Juan), 2: 57- 60.

Brown, D.A. 1948. Six new Recent and Tertiary genera of cheilostomatous Polyzoa from New Zealand. Annals and Magazine of Natural History, series 12, 1: 108-122.

Brown, D.A. 1952. The Tertiary cheilostomatous Polyzoa of New Zealand. Trustees of the British Museum (Natural History), London, $405 \mathrm{p}$.

Busk, G. 1852. An account of the Polyzoa, and sertularian zoophytes, collected in the Voyage of the Rattlesnake, on the coasts of Australia and the Louisiade Archipelago. In: J. MacGillivray (Ed.), Narrative of the Voyage of the H.M.S. Rattlesnake, T. \& W. Boone, London, 1: 343-402.

Busk, G. 1854. Catalogue of marine Polyzoa in the collection of the British Museum. II. Cheilostomata (part.). Trustees of the British
Museum (Natural History), London, p. 55-120.

Busk, G. 1884. Report on the Polyzoa collected by H.M.S. Challenger during the years 1873-1876. Part 1. The Cheilostomata. Report on the Scientific Results of the Voyage of the H.M.S. Challenger: Zoology 10: 1-216.

Canu, F. 1904. Les bryozoaires du Patagonien. Échelle des bryozoaires pour les terrains tertiaires. Mémoires de la Société Géologique de France, Paléontologie 12: 1-30.

Canu, F. 1908. Iconographie des bryozoaires fossiles de l'Argentine. Première partie. Anales del Museo Nacional de Buenos Aires, 10: 245-341.

Canu, F. 1911. Iconographie des bryozoaires fossiles de l'Argentine. Deuxième partie. Anales del Museo Nacional de Buenos Aires 14: 214-288.

Carmona, N.B., Buatois, L.B., Mángano, M.G., and Bromley, R.G. 2008. Ichnology of the Lower Miocene Chenque Formation, Patagonia, Argentina: animal - substrate interactions and the Modern Evolutionary Fauna. Ameghiniana 45: 93-122.

Cuitiño, J.I., Scasso, R.A., Ventura Santos, R., and Mancini, L.H. 2015. $\mathrm{Sr}$ ages for the Chenque Formation in the Comodoro Rivadavia region (Golfo San Jorge Basin, Argentina): Stratigraphic implications. Latin American Journal of Sedimentology and Basin Analysis 22: 3-12.

del Río, C.J., Martínez, S., McArthur, J., Matthew, T., and Pérez, L.M. 2018. Dating late Miocene marine incursions with Sr-Isotope stratigraphy (Argentina and Uruguay): a reappraisal of the peleogeography of the "Paranense" sea. Journal of South American Earth Sciences 85: 312-334.

Ehrenberg, C.G. 1831. Animalia invertebrata exclusis insects. Symbolae Physicae, seu Icones et descriptiones Corporum Naturalium novorum aut minus cognitorum. Pars Zoologica 4: 1-831.

Gordon, D.P. 1982. The genera of the Chaperiidae (Bryozoa). New Zealand Journal of Zoology 9: 1-24.

Gordon, D.P. 1984. The marine fauna of New Zealand: Bryozoa: Gymnolaemata from the Kermadec Ridge. New Zealand Oceanographic Institute Memoir 91: 1-198.

Gordon, D.P. 1986. The marine fauna of New Zealand: Bryozoa: Gymnolaemata (Ctenostomata and Cheilostomata Anasca) from the western South Island continental shelf and slope. New Zealand Oceanographic Institute Memoir 95: 1-121.

Harmer, S.F. 1926. The Polyzoa of the Siboga Expedition. Part 2. Cheilostomata Anasca. Siboga Expedition Reports 28b: 181-501.

Hayward, P.J., and Cook, P.L. 1979. The South African Museum's Meiring Naude cruises. Part 9. Bryozoa. Annals of the South African Museum 79: 43-130.

Hayward, P.J., and Thorpe, J.P. 1988. Species of Chaperiopsis (Bryozoa, Cheilostomata) collected by Discovery investigations. Journal of Natural History 22: 45-69.

Hayward, P.J., and Winston, J.E. 2011. Bryozoa collected by United States Antarctic Research Program: new taxa and new records. Journal of Natural History 45: 2259-2238.

Jullien, J. 1888. Bryozoaires. In: Mission Scientifique du Cap Horn, 1882-1883, Zoologie 6. Gauthier-Villars et Cie., Paris, p. 1-94.

Kluge, G.A. 1914. Die Bryozoen der Deutschen Südpolar-Expedition 1901-1903. I. Die Familien Aetidae, Cellularidae, Bicellaridae, Farciminaridae, Flustridae, Membraniporidae und Cribrilinidae. Deutsche Südpolar-Expedition, 15, Zoologie 7. G. Reimer, Berlin, p. 601-678.

Lamouroux, J.V.F. 1825. Description des polypiers flexibles. In: J.R.C. Quoy, and J.P. Gaimard (Eds.), Voyage autour du monde executé par les corvettes S.M. I'Uranie et la Physicienne pendant les années 1817-1820, 3, Zoologie IV. Pillet Ane, Paris, p. 603-642. 
López Gappa, J. 2000. Species richness of marine Bryozoa in the continental shelf and slope off Argentina (south-west Atlantic). Diversity and Distributions 6: 15-27.

López Gappa, J., and Lichtschein, V. 1988. Geographic distribution of bryozoans in the Argentine Sea (South-Western Atlantic). Oceanologica Acta 11: 89-99.

López-Gappa, J., Pérez, L.M., and Griffin, M. 2017. First record of a fossil selenariid bryozoan in South America. Alcheringa 41: 365-368.

López-Gappa, J., Pérez, L.M., and Griffin, M. 2018. First fossil occurrence of the genus Platychelyna Hayward and Thorpe (Bryozoa: Cheilostomata). Ameghiniana 55: 607-612.

Maplestone, C.M. 1899. Further descriptions of the Tertiary Polyzoa of Victoria. Part II. Proceedings of the Royal Society of Victoria 12: 1-13.

Marcus, E. 1955. Notas sobre briozoos marinhos brasileiros. Arquivos do Museu Nacional do Rio de Janeiro 42: 273-341.

Miotti, L. 1992. Paleoindian occupation at Piedra Museo locality, Patagonian Region, Argentina. Current Research in the Pleistocene 9: 30-31.

Norman, A.M. 1903. Notes on the natural history of East Finmark. Annals and Magazine of Natural History series 7, 12: 87-128.

Ortmann, A.E. 1900. Synopsis of the collections of invertebrate fossils made by the Princeton Expedition to Southern Patagonia. American Journal of Science 10: 368-381.

Ortmann, A.E. 1902. Paleontology Part II. Tertiary Invertebrates. In: W.B. Scott (Ed.), Reports of the Princeton University Expeditions to Patagonia, 1896-1899. Vol. 4, Paleontology I, part 2. J. Pierpont Morgan Publication Fund, Princeton, p. 45-332.

Panza, J.L. 1998. Hoja Geológica 4969-11. Monumento Natural Bosques Petrificados. Provincia de Santa Cruz. Dirección Nacional del Servicio Geológico. Boletín n² 214. Secretaría de Minería de la Nación. Buenos Aires, Argentina.

Paredes, J., and Colombo, F. 2001. Sedimentología de la Formación Chenque (Oligoceno-Mioceno) en Comodoro Rivadavia. Argentina. Geogaceta 30: 103-106.

Parras, A., and Griffin, M. 2009. Darwin's Great Patagonian formation at the mouth of the Santa Cruz River: a reappraisal. Revista de la Asociación Geológica Argentina 9: 70-82.

Parras, A., Dix, G., and Griffin, M. 2012. Sr-isotope chronostratigraphy of Paleogene- Neogene marine deposits: Austral Basin, southern Patagonia (Argentina). Journal of South American Earth Sciences 37: 122-135.

Pérez, L.M., Griffin, M., Pastorino, G., López-Gappa, J., and Manceñido, M.O. 2015a. Redescription and palaeoecological significance of the bryozoan Hippoporidra patagonica (Pallaroni, 1920 ) in the San Julián Formation (late Oligocene) of Santa Cruz province, Argentina. Alcheringa 39: 1-7.
Pérez, L.M., López-Gappa, J., and Griffin, M. 2015b. New and littleknown bryozoans from Monte León Formation (Early Miocene, Argentina) and their paleobiogeographic relationships. Journal of Paleontology 89: 956-965.

Pérez, L.M., López-Gappa, J., and Griffin, M. 2018. Taxonomic status of some species of Aspidostomatidae (Bryozoa: Cheilostomata) from the Oligocene and Miocene of Patagonia (Argentina). Journal of Paleontology 92: 432-441.

Prud'homme, J. 1961. Le genre Amphiblestrella: nouveau genre de bryozoaires cheilostomes. Bulletin de la Société Géologique de France 2: 947-950.

Ramalho, L., and Calliari, L. 2015. Bryozoans from Rio Grande do Sul Continental Shelf, Southern Brazil. Zootaxa 3955: 569-587.

Uttley, G.H. 1949. The Recent and Tertiary Polyzoa (Bryozoa) in the collection of the Canterbury Museum, Christchurch. Records of the Canterbury Museum 5: 167-192.

Uttley, G.H., and Bullivant, J.S. 1972. Biological results of the Chatham Islands 1954 Expedition. Part 7. Bryozoa Cheilostomata. New Zealand Oceanographic Institute Memoir 57: 1-61.

Vieira, L.M., Gordon, D.P., Souza, F.B.C., and Haddad, M.A. 2010. New and little-known cheilostomatous Bryozoa from the south and southeastern Brazilian continental shelf and slope. Zootaxa 2722: 1-53.

Waters, A.W. 1887. On Tertiary chilostomatous Bryozoa from New Zealand. Quarterly Journal of the Geological Society 43: 40-72.

Waters, A.W. 1898. Observations on Membraniporidae. Journal of the Linnean Society (Zoology) 26: 654-693.

Waters, A.W. 1904. Bryozoa. Résultats du Voyage du S. Y. 'Belgica' en 1897-99, Zoologie, Expedition Antarctique Belge 4: 1-114.

Wilson, M.A., and Taylor, P.D. 2006. Predatory drill holes and partial mortality in Devonian colonial metazoans. Geology 34: 565-568.

Zágorsek, K. 2001. Eocene Bryozoa from Hungary (part II. Systematic palaeontology). Courier Forschungsinstitut Senckenberg 231: 19-159.

doi: 10.5710/AMGH.30.08.2019.3281

Submitted: July $18^{\text {th }}, 2019$

Accepted: August 30 3019

Published online: September $9^{\text {th }}, 2019$ 